Reprod. Nutr. Dévelop., 1980, 20 (1 B), 339-347.

\title{
Adrenal maturation of the sheep fetus during late pregnancy
}

\author{
Pai Ph. DURAND, M. J. BOSC, A. LOCATELLI \\ Station de Physiologie de la Reproduction, I.N.R.A. \\ Nouzilly 37380 Monnaie, France.
}

\begin{abstract}
Summary. The mechanism by which adrenal growth is achieved and steroidogenesis is stimulated in the fetal lamb during late pregnancy has been studied. Fetal plasma ACTH levels remained roughly constant between 14 and 3 days pre partum $(298 \pm 38 \mathrm{pg} / \mathrm{ml})$, then increased to a mean of $634 \pm 89 \mathrm{pg} / \mathrm{ml}$. The rise in ACTH did not occur before the pre partum rise in cortisol. The increase in adrenal weight was achieved in three periods, one of DNA duplication between two phases of cellular hypertrophy. Cellular hypertrophy was accompanied by an important biosynthesis of membrane proteins. This development might partly explain the increased production rate of cortisol by the fetal adrenals during late pregnancy. At the same time, the number of ACTH receptors per 2 adrenals increased 5 -fold. There was a close correlation befween the levels of fetal plasma corticosteroids and the number of ACTH receptors during late pregnancy. It has been suggested that receptor modulation is one of the factors responsible for the enhanced sensitivity of the fetal adrenals to ACTH just before parturition. Preliminary results on the endocrine regulation of that development are alșo presented.
\end{abstract}

\section{Introduction.}

In many mammalian species, an important increase in plasma corticosteroids is a common feature of the fetal endocrine milieu during late pregnancy. In the sheep, this increase in cortisol, necessary for the maturation of some fetal organ systems (adrenal medulla : Comline et al., 1970 ; liver : Liggins, 1969 ; lungs : De Lemos ef al., 1970 ; pancreas : Bassetf et al., 1973 ; haemopoietic system : Pierce et al., 1976), is also responsible for the onset of parturition (Liggins ef al., 1973). The rise in fetal sheep cortisol levels during the last 2 weeks of gestation (Bassett and Thorburn, 1969 : Liggins et al., 1973) develops simultaneously with an enlargement of the adrenal glands (Comline and Silver, 1961). This pre-partum burst of adrenocortical function involves the influence of hypophyseal factors. Indeed, it has been shown that removal of the fetal pituitary abolishes the increase in cortisol (Challis et al., 1977b), whereas perfusion with adrenocorticotropin (ACTH) stimulates the fetal adrenals at about 100 days of pregnancy, resulting in premature parturition (Liggins, 1968). However, under physiological conditions the relationship between ACTH and cortisol during late pregnancy is not clear. On the other hand, accumulating evidence suggests a change in the sensitivity of the fetal adrenal to ACTH near term (Madill and Basset, 1973 ; Wintour et al., 1975). The 
purpose of the present study was to obtain more information on the mechanism by which fetal adrenal growth is achieved and steroidogenesis is stimulated during late pregnancy. We report here the variations in the plasma ACTH levels in the sheep fetus, and the DNA, protein and ACTH receptor concentrations in the fetal adrenal glands during the perinatal period. Preliminary results on the endocrine regulation of these parameters are also presented.

\section{Material and methods.}

Animals. - Cross-bred fetuses and lambs (Ile-de-France $\times$ Romanov-lle-de-France) from single or multiple pregnancies were used. The day of fertilizing insemination was considered as day 0 of pregnancy. The fetuses were obtained by caesarean section under general anesthesia. The adrenal glands and the blood for cortico-steroid assay were sampled at slaughter.

Sampling for ACTH assay. - Vascular silastic catheters were implanted into a fetal artery (carotid or femoral) according to Dawes et al. (1972). Samples (2 ml) were taken between $9 \mathrm{~h} 00$ and $12 \mathrm{~h} 00$ at least 24 hrs after surgery in cold tubes containing EDTA as an anticoagulant. The plasma was removed by centrifugation at $1500 \mathrm{~g}$ and $4{ }^{\circ} \mathrm{C}$ for $10 \mathrm{~min}$, then stored at $-20^{\circ} \mathrm{C}$.

Perfusion of fetuses. - The fetuses were infused by the intraperitoneal route as follows : after laparotomy under light anesthesia (fluothane, $\mathrm{O}_{2}$ ) the catheter was inserted into the fetal peritoneal cavity through a needle which was then withdrawn. The extremity of the catheter was fixed to the skin of the fetus and two holes were drilled on the tube $1 \mathrm{~cm}$ from its distal end. The free end of the catheter was then connected to a perfusion pump. ACTH ${ }_{1-24}$ and metyrapone (metopirone, $\mathrm{Ciba}$ ), an inhibitor of $11 \beta$-hydroxylase, were dissolved each day in 4.8 or $10.6 \mathrm{ml}$ of $0.9 \mathrm{p} .100 \mathrm{NaCl}$ solution wich was infused at a constant rate over the next $24 \mathrm{hrs}$.

ACTH assay. - Plasma ACTH was determined by radioimmunoassay according to Berson and Yalow (1968) without extraction but with a control of the ACTH degradation during incubation. The ACTH used for standardization and iodination was synthetic $\mathrm{ACTH}_{1-24}$ (Synacthen, Ciba). The antibody employed (ACTH-K, CEA) was raised in the rabbit using ACTH coupled to BSA. Parallelism of immunoreactivity between the standard $\mathrm{ACTH}_{1-24}$ and serial dilutions of sheep plasma was observed (not shown). Other methods. - DNA, proteins, ACTH receptors and plasma corticosteroids were assayed as described elsewhere (Durand et al., 1978 ; Durand, 1979).

\section{Results and discussion.}

Plasma ACTH levels. - The plasma ACTH concentrations in lamb fetuses from 14 days before parturition until $1 \mathrm{hr}$ post-partum are shown in figure 1 . Despite the small number of values, ACTH levels clearly remained roughly constant between 14 and 3 days pre-partum, with a mean value of $298 \pm 38 \mathrm{pg} / \mathrm{ml}$. In the last 3 days of gestation, however, ACTH levels rose in most, buf not all, fetuses, the mean concentration being $634 \pm 89 \mathrm{pg} / \mathrm{ml}(\mathrm{P}<0.01)$. Finally, plasma ACTH appeared to decrease 
promptly after parturition to levels lower than all the other values in late pregnancy. These results are in agreement with other data (Rees ef al., 1975 ; Challis et al., 1977a; Jones et al., 1977a) and confirm that ACTH levels rise only in the very last days of gestation, when cortisol levels are already elevated (Bassett and Thorburn, 1969 ; Liggins ef al., 1973). In addition, Jones et al. (1977a) have shown that ethanol infused into the fetus during labour, significantly reduces ACTH concentration, but that no changes in fetal plasma cortisol levels are associated with changes in ACTH concentrations. Hence, it appears that the pre-partum rise in fetal cortisol levels is not directly correlated with an increase in plasma ACTH.

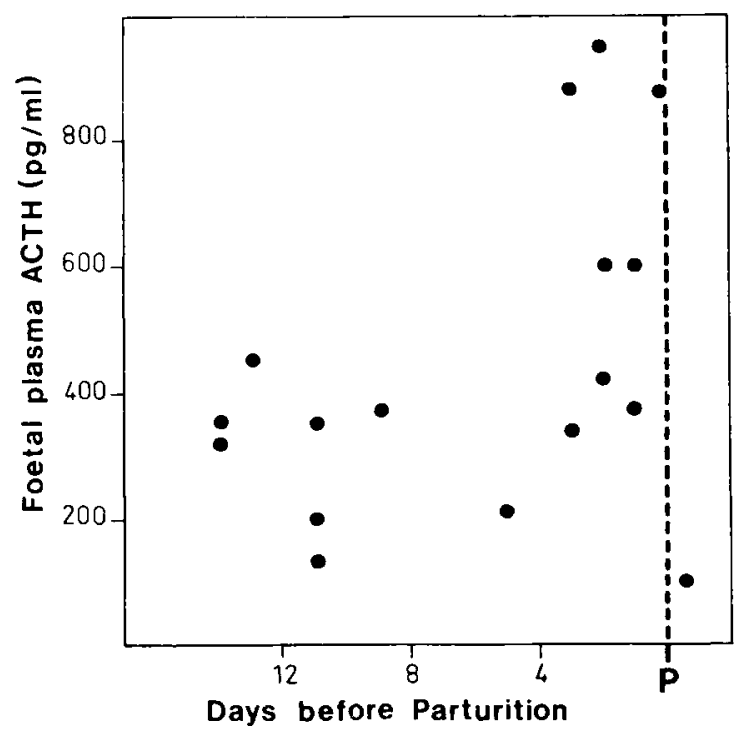

FIG. 1. - Plasma ACTH levels in chronically catheterized lamb fetuses during the last 2 weeks of pregnancy.

However, in vitro (Anderson et al., 1972 ; Madill and Bassett, 1973 ; Wintour ef al.,) 1975) and in vivo (Liggins et al., 1973 ; Bassett and Thorburn, 1973 ; Jones et al., 1977b) studies have presented evidence for an enhanced responsiveness of the fetal adrenal to ACTH near term; the course and the mechanisms of this adrenal maturation are poorly documented. Several factors have been suggested as being responsible :

— increased cortical mass (Comline and Silver, 1961 ; Nathanielsz et al., 1972), but this may be a consequence, and not a cause, of the enhanced responsiveness. In addition, it could be achieved either by an increase in the number of cells or by hypertrophy of the adrenal cells;

- enhanced ACTH uptake by the cortical cells, possibly due to an increase in the number or the affinity of ACTH receptors ;

- maturation of the enzymes implicated in cortisol biosynthesis. Wintour et al. (1975) have shown, however, that between days 60 and 90 of gestation the fetal adrenal in vitro produces large quantitaties of cortisol when stimulated by ACTH. This hypothesis is therefore unlikely. 
To learn more about this adrenal maturation, we have studied the changes in protein, DNA and ACTH receptor concentrations in the fetal sheep adrenal glands during the perinatal period.

Changes in DNA and membrane synthesis. - The table shows that during late pregnancy adrenal weight increased 2.5 -fold $(P<0.001)$, and membrane protein content augmented by a factor of $4(P<0.001)$. The postnatal variations of these fwo parameters were not significant. The DNA pattern showed that this development was achieved in only one period of DNA duplication between days 136 and $143(P<0.05)$. Nathanielsz et al. (1972) and Durand ef al. (1978) reported that this growth essentially concerned the adrenal cortex ; thus, the increase in DNA should correspond roughly to a doubling in the number of cortical cells. The wet weight: DNA ratio (see table 1) gave evidence of two phases of cellular hypertrophy, one between days 124 and 136, the other between day 143 and birth. These two phases were accompanied by increased biosynthesis of total membrane proteins. This membrane fraction consisted not only of plasma membrane but also of smooth endoplasmic reticulum membrane, mitochondria, structures participating in steroid synthesis. The development of that fraction probably enhanced the ability of the cortical cells to synthesize corticosteroids. This, together with the increased cell number, could partly explain the enhanced pre-partum production rate of cortisol by the fetal adrenal glands (Liggins et al., 1973).

\section{TABLE 1}

Changes in membrane protein and DNA contents of fetal sheep adrenal glands during late pregnancy and the early neonatal period (mean \pm SE for at least 7 animals)

\begin{tabular}{|c|c|c|c|c|c|c|}
\hline \multirow{2}{*}{ Age } & \multicolumn{4}{|c|}{ Before birth (days of pregnancy) } & \multicolumn{2}{|c|}{ After birth (days) } \\
\hline & 124 & 136 & 140 & 144 & Birth (0) & 3 \\
\hline Wet weight $(\mathrm{mg})$. & $279 \pm 18$ & $346 \pm 29$ & $376 \pm 26$ & $469 \pm 28$ & $704 \pm 62$ & $695 \pm 27$ \\
\hline $\mathrm{DNA}(\mathrm{mg}) \ldots$ & $0.586 \pm 0.060$ & $0.630 \pm 0.074$ & $0.706 \pm 0.054$ & $0.839 \pm 0.049$ & $0.888 \pm 0.112$ & $20.870 \pm 0.04$ \\
\hline $\begin{array}{c}\text { Membrane proteins } \\
(\mathrm{mg}) \ldots \ldots \ldots \ldots \ldots \\
\end{array}$ & $3.13 \pm 0.25$ & $5.09 \pm 0.61$ & $5.83 \pm 0.28$ & $8.04 \pm 0.49$ & $12.10 \pm 1.08$ & $12.72 \pm 0.80$ \\
\hline Wet weight/DNA & $512 \pm 56$ & $613 \pm 51$ & $535 \pm 31$ & $539 \pm 38$ & $838 \pm 57$ & $791 \pm 48$ \\
\hline Prolein/DNA & $5.87 \pm 0.74$ & $8.67 \pm 1.13$ & $8.54 \pm 0.82$ & $9.12 \pm 0.61$ & $14.25 \pm 0.81$ & $14.55 \pm 1.46$ \\
\hline
\end{tabular}

(Data from Durand et al., 1978.)

Hormonal regulation of the growth of the adrenal cortex in late pregnancy is not well understood. The termination of adrenal growth in lamb fetuses hypophysectomized on day 115 was demonstrated by Liggins (1969), whereas large doses of ACTH anticipated the increase in adrenal weight (Liggins, 1968). Figure 2 shows that the infusion of $0.1 \mathrm{mg} / 24 \mathrm{~h}$ of ACTH into the sheep fetus between days 115 and 120 resulted in a 4-fold increment in adrenal membrane protein content and a 2-fold increase in DNA concentrations. However, as opposed to Liggins' data (1968), simultaneous perfusion of 
metyrapone $(100,200$ or $440 \mathrm{mg} / 24 \mathrm{~h})$ with ACTH $(0.1 \mathrm{mg} / 24 \mathrm{~h})$ did not block the enlargement of the glands and the increase in DNA $(P<0.01)$ and membrane protein $(P<0.01)$ contents. Alternatively, the perfusion of $300 \mathrm{mg} / 24 \mathrm{~h}$ of metyrapone to the fetuses between days 139 and 143 resulted in an increment in the membrane protein content of the adrenal glands $(P<0.001)$ without any significant change in DNA concentration (fig. 2). This was probably due to an increase in endogenous ACTH secretion under the influence of the blockade of cortisol biosynthesis. However, physiologically, ACTH rises only at the end of pregnancy, hence we should examine the influence of increased cortical cell sensitivity to ACTH as well as the role of other possible trophic hormones.

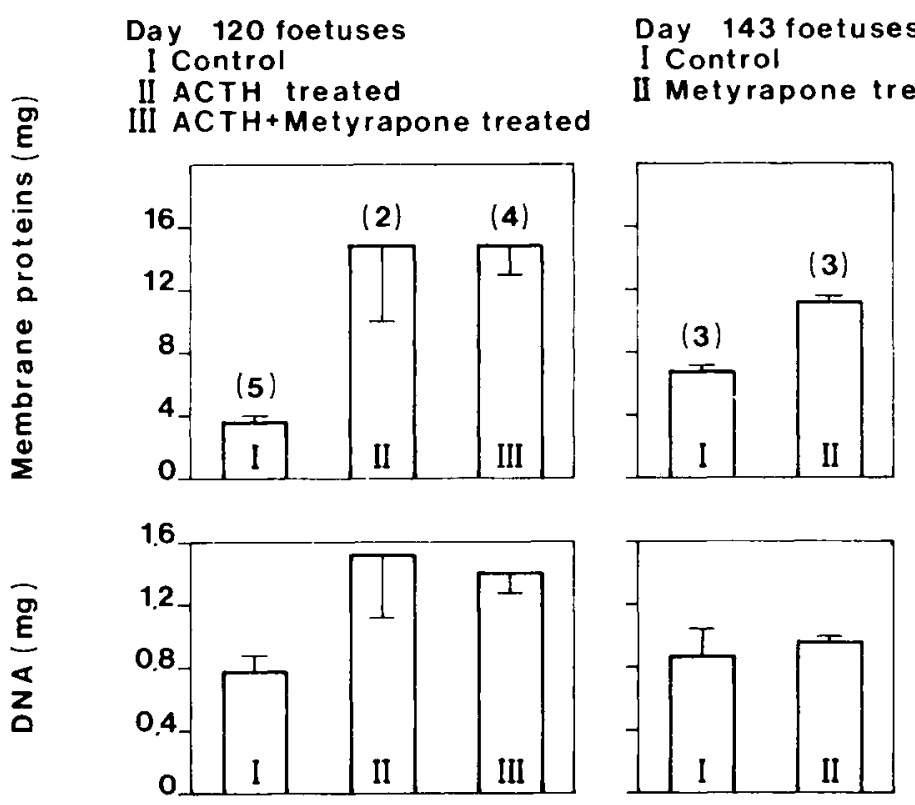

FIG. 2. - Effect of infusion of ACTH, ACTH and metyrapone, or metyrapone olone into the sheep fetus on membrane protein and DNA levels of the fetal adrenals. Left : 115-day old fetuses infused for 5 days with ACTH $1_{-24}(0.1 \mathrm{mg} / 24 \mathrm{~h})$ or ACTH $\mathrm{1}_{-24}(0.1 \mathrm{mg} / 24 \mathrm{~h})+$ metyrapone $(100,200$ or $440 \mathrm{mg} / 24 \mathrm{~h})$. Right : 139-day old fetuses infused for 4 days with $300 \mathrm{mg} / 24 \mathrm{~h}$ of metyrapone. Each point represents the mean \pm SE for the number of animals indicated in parenthesis.

ACTH receptor levels in lamb fetuses. - Figure 3 shows that the number of ACTH receptors per 2 adrenal glands increased 5 -fold between day 124 of pregnancy and birth $(P<0.001)$. This increase was biphasic, reflecting not only and increment in cell number, but also an increase in the number of receptors per cell (Durand, 1979). No significant variations in binding affinity were observed during that period. Figure 3 also presents corticosteroid level variations in the blood of these same fetuses and newborn lambs; the classical rise in cortisol at the end of gestation and the post-partum drop were observed. The correlation coefficient of every single point between the 
apparent number of ACTH receptors and the corticosteroid levels at the end of pregnancy was $r=0.57 ; P<0.01(n=28)$.

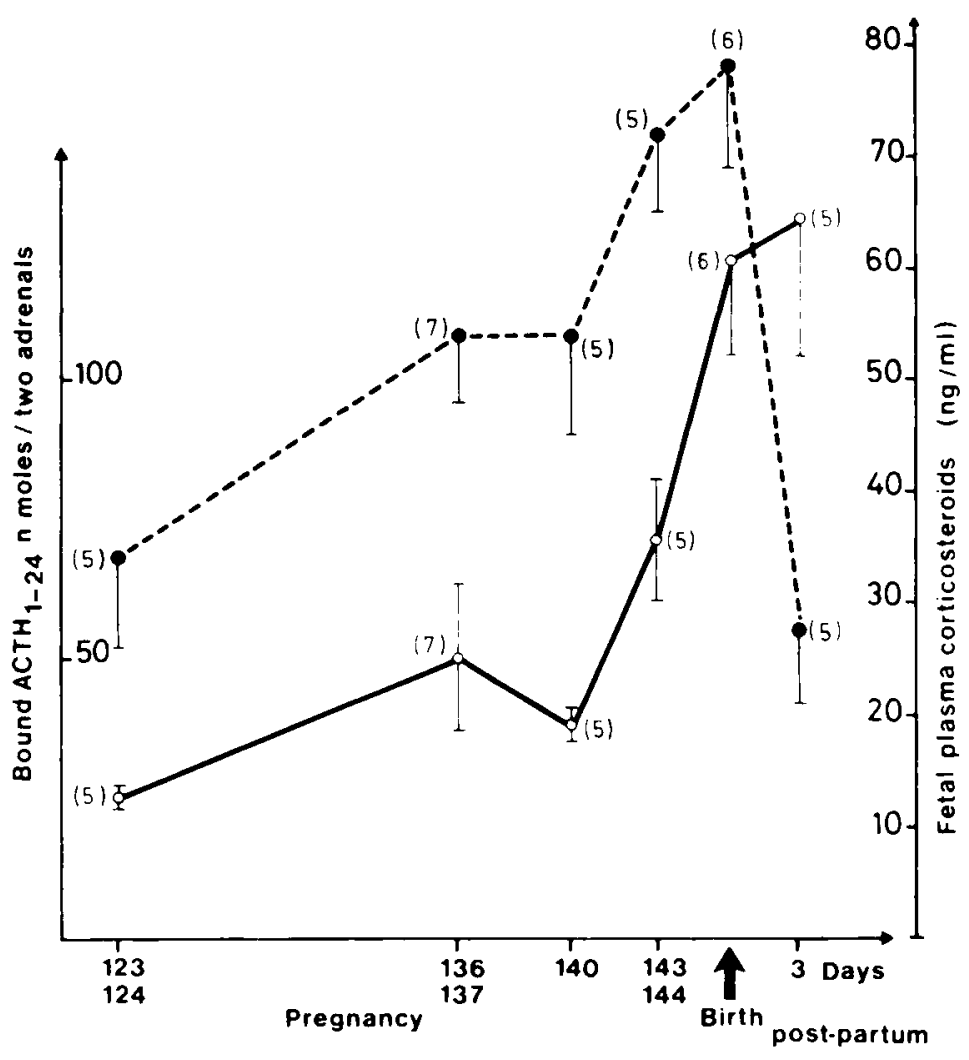

FIG. 3. - Change in the number of ACTH receptors (per 2 adrenals) (0- 0 ) in fetal lamb adrenals at the end of pregnancy, and in lamb adrenals after parturition. $\cdots=$ plasma corticosteroid levels of the same fetuses and lambs. (Data from Durand, 1979.)

Thus, it appears that fetal sheep adrenals undergo fundamental alterations in late gestation which result in a striking increase in ACTH receptors. This increment is closely correlated with the results obtained by Madill and Bassett (1973) and by Wintour ef al. (1975) in which the response to ACTH was found to develop during the last weeks of gestation. The data summarized above suggest that receptor modulation was one of the factors involved in that maturation. It might be relevant to add that there was a very rapid decrement in corticosteroid levels after birth, despite the high levels of ACTH receptors; this might be due to a change in the sensitivity of the negative feedback between cortisol and ACTH at birth. Indeed, the sensitivity of this mechanism was probably very poor during the last 3 days of gestation, since at that time ACTH and cortisol levels rose parallelly (figs. 1 and 3 ). 
The endocrinological determinism of the gradually developing sensitivity of the adrenals to $\mathrm{ACTH}$ remains to be elucidated. The preliminary results presented in figure 4 suggested that self-regulation of the $A C T H$ receptors might be operating in the
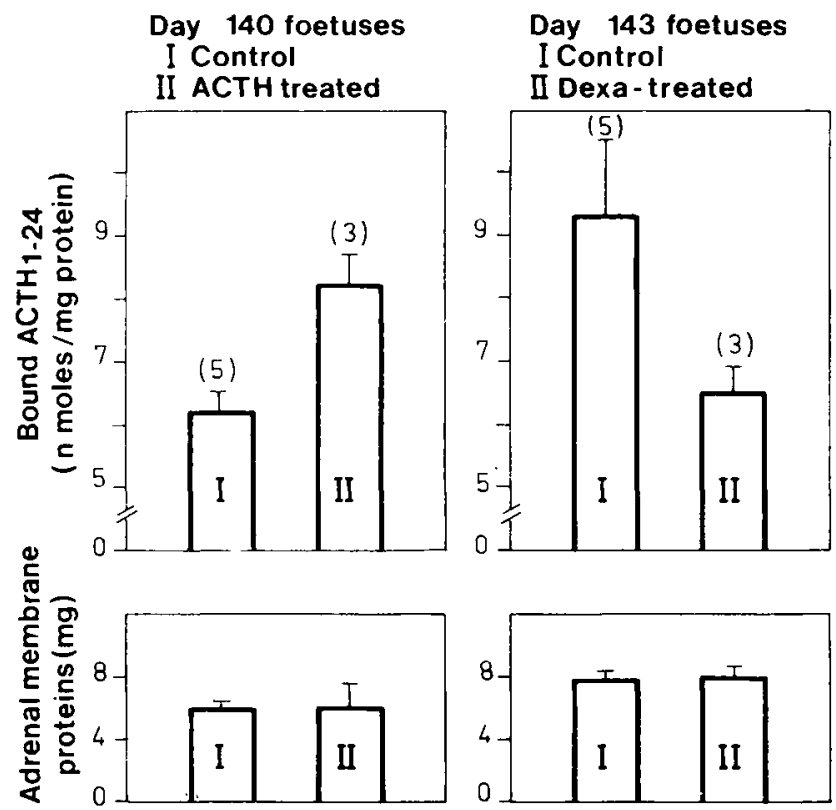

FIG. 4. - Effect of short ACTH infusion into sheep fetuses and of repeated dexamethasone injections to the dam on the number of ACTH receptors in the fetal adrenals. Left : 138-day old fetuses infused for 2 days with $\mathrm{ACTH}_{1-24}(0.1 \mathrm{mg} / 24 \mathrm{~h})$. Right : dam given a daily i.m. dose of $32 \mathrm{mg}$ of dexamethasone $(2 \times 16 \mathrm{mg})$ on days 141 and 142 ; lambing occurred at day 143 . Results are expressed in nmoles $\mathrm{ACTH}_{1-24}$ bound per $\mathrm{mg}$ of protein. Each point represents the mean $\pm \mathrm{SE}$ for the number of animals shown in parenthesis. Adrenal membrane protein content is also shown.

sheep at that period ; a $48 \mathrm{hr}$ ACTH infusion into the fetus between days 138 and 140 increased the apparent number of $\mathrm{ACTH}$ receptors, expressed per $\mathrm{mg}$ of protein $(P<0.01)$, without changing the membrane protein content of the adrenals. Conversely, repeated injections of dexamethasone to the mother, which momentarily inhibit the fetal pituitary-adrenal axis (Bosc and Fèvre, 1974), reduced the number of ACTH binding sites, but this variation was not significant. Hence, further investigations are needed to specify the role of ACTH. In addition, it has been shown recently that other hormones, such as $\mathrm{PGE}_{2}$ (Louis et al., 1976) and $\alpha-\mathrm{MSH}$ (Glickman et al., 1979), can increase cortisol secretion by the fetal sheep adrenals. Thus, it appears that ACTH is not the sole factor involved in this regulation, and that synergistic or inhibiting factors actually modulate its effects.

$5^{e}$ Réunion du groupe Développement I.N.R.A., Clermont-Ferrand/Theix, 17-18 mai 1979.

Acknowledgements. - We thank Dr. Meredith Lemon-Resplandy for help in preparing the English translation. 
Résumé. Les modalités de la croissance des surrénales et la régulation de leur stéroïdogenèse ont été étudiées chez le fœtus ovin à la fin de la gestation. Les concentrations de I'ACTH plasmatique, chez le foetus, restent sensiblement constantes entre 14 et 3 jours pre partum $(298 \pm 38 \mathrm{pg} / \mathrm{ml})$. Elles s'élèvent alors jusqu'à une valeur moyenne de $634 \pm 89 \mathrm{pg} / \mathrm{ml}$. L'augmentation de l'ACTH ne précède pas la montée pre-partum du cortisol. L'augmentation pondérale des surrénales s'effectue selon deux phases d'hypertrophie cellulaire séparées par une période de réplication de l'ADN. Ces deux phases d'hypertrophie s'accompagnent d'une importante synthèse de protéines membranaires. Ce développement doit, en partie, rendre compte de l'augmentation de la production de cortisol par les surrénales fœtales en fin de gestation. Parallèlement, le nombre de récepteurs de l'ACTH, exprimé pour les 2 surrénales, est multiplié par 5 . II existe une corrélation étroite entre les niveaux plasmatiques des corticostéroïdes fœetaux et le nombre de récepteurs de l'ACTH, pendant la fin de la gestation. Ces résultats suggèrent que la modulation du nombre des récepteurs est un des facteurs impliqués dans l'augmentation de la sensibilité à l'ACTH des surrénales fotales juste avant la parturition.

\section{References}

ANDERSON A. B. M., PIERREPOINT C. G., GRIFFITH K., TURNBULL A. C., 1972. Steroid metabolism in the adrenals of foetal sheeps in relation to natural and corticotrophin-induced parturition in sheep. J. Reprod. Fert., suppl. 16, 25-37.

BASSETT J. M., THORBURN G. D., 1969. Foetal plasma corticosteroids and the initiation of parturition in the sheep. J. Endocr., 44, 285-286.

BASSETT J. M., THORBURN G. D., 1973. Circulating levels of progesterone and corticosteroids in the pregnant ewe and its foetus, 126-140. In PIERREPOINT C. G., Endocrinology of pregnency and parturition. Experimental studies in the sheep. Alpha omega alpha, Cardiff.

BASSETT J. M., THORBURN G. D., NICOL D. H., 1973. Regulation of insulin secretion in the ovine fetus in utero. Effects of sodium valerate on secretion and of adrenocorticotrophin-induced premature parturition on the insulin secretory response to glucose. J. Endocr., 56, 13-25.

BERSON S. A., YALOW R. S., 1968. Radioimmunoassay of ACTH in plasma. J. clin. Invest., 47, 27252751.

BOSC M. J., FÈVRE J., 1974. Etude du mode d'action de la dexamethasone utilisée pour induire l'agnelage chez la brebis. C. R. Acad. Sci. Paris, Sér. D, 278, 315-318.

CHALLIS J. R. G., JONES C. T., ROBINSON J. S., THORBURN G. D., $1977 a$. Development of fetal pituitary-adrenal function. J. Steroid Biochem., 8, 471-478.

CHALLIS J. R. G., KENDALL J. Z., ROBINSON J. S., THORBURN G. D., 1977b. The regulation of corticosteroids during late pregnancy and their role in parturition. Biol. Reprod., 16, 57-69.

COMLINE R. S., SILVER M., 1961. The release of adrenaline and noradrenaline from the adrenal glands of the foetal sheep. J. Physiol. Lond., 156, 424-444.

COMLINE R. S., SILVER M., SILVER I. A., 1970. Effect of foetal hypophysectomy on catecholamine levels in the lamb adrenal during prolonged gestation. Nature, 225, 739-740.

DAWES G. S., FOX H. E., LEDUC B. M., LIGGINS G. C., RICHARD R. T., 1972. Respiratory movements and rapid eye movement sleep in the foetal lamb. J. Physiol. Lond., 220, 119-143.

DE LEMOS R. A., SHERMETA D. W., KNELSON J. H., KOTAS R., AVERYM. E., 1970. Acceleration of appearance of pulmonary surfactant in the fetal lamb by administration of corticosteroids. Am. Rev. Respir. Did., 102, 459-461.

DURAND Ph., 1979. ACTH receptor levels in lamb adrenals at late pregnancy and early neonatal stages. Biol. Reprod., 20, 837-845.

DURAND Ph., BOSC M. J., NICOLLE A., 1978. Croissance des surrénales de foetus ovin en fin de gestation : évolution de l'ADN et des protéines membranaires. C. R. Acad. Sci. Paris, Sér. D, 287, 297-300.

GLICKMAN J. A., CARSON G. D., CHALLIS J.R.G., 1979. Differential effects of synthetic adrenocorticotropin ${ }^{1-24}$ and $\alpha$ Melanocyte-stimulating hormone on adrenal function in human and sheep fetuses. Endocrinology, 104, 34-39. 
JONES C. T., BODDY K., ROBINSON J. S., 1977a. Changes in the concentration of adrenocorticotrophin and corticosteroid in the plasma of foetal sheep in the latter half of pregnancy and during labour. J. Endocr., 72, 293-300.

JONES C. T., BODDY K., ROBINSON J. S., RATCLIFE J. C., 1977b. Developmental changes in the responses of the adrenal gland of foetal sheep to endogenous adrenocorticotrophin, as indicated by hormone response to hypoxemia. J. Endocr., 72, 279-292.

LIGGINS G. C., 1968. Premature parturition after infusion of corticotrophin or cortisol into foetal lambs. J. Endocr., 42, 323-329.

LIGGINS G. C., 1969. The foetal role in the initiation of parturition in the ewe, 218-244. In WOLSTENHOLM G. E. W., O'CONNOR M., Foetal autonomy, Churchill, London.

LIGGINS G. C., FAIRCLOUGH R. J., GRIEVES S. A., KENDALL J. Z., KNOX B. S., 1973. The mechanism of initiation of parturition in the ewe. Recent. Progr. Horm. Res., 29, 111-150.

LOUIS T. M., CHALLIS J. R. G., ROBINSON J. S., THORBURN G. D., 1976. Rapid increase of foetal corticosteroids after prostaglandin E2. Nature, 264, 797-799.

MADILL D., BASSETT J. M., 1973. Corticosteroid release by adrenal tissue from foetal and newborn lambs in response to corticotrophin stimulations in a perifusion system in vitro. J. Endocr., 58, 75-87.

NATHANIELSZ P. W., COMLINE R. S., SILVER M., PAISEY R. B., 1972. Cortisol metabolism in the foetal and neonatal sheep. J. Reprod. Fertil. Suppl., 16, 39-59.

PIERCE K., CLEGG J., DAWES G. S., ROBINSON J. S., THORBURN G. D., WEATHERALL D., WOOD B., 1976. Unpublished observations.

REES L. H., JACK P. M. B., THOMAS A. L., NATHANIELSZ P. W., 1975. Role of foeta ladrenocorticotrophin during parturition in sheep. Nature, 253, 274-275.

WINTOUR E. M., BROWN E. H., DENTON D. A., HARDY K. J., MCDOUGALL J. G., ODDIE C. J., WHIPP, G. T., 1975. The ontogeny and regulation of corticosteroid secretion by the ovine foetal adrenal. Acta endocr., 79, 301-316. 